\title{
İHRACAT KREDİ SİGORTASININ ÖNEMİ: TÜRKIYYE ÖRNEĞİ
}

\author{
IMPORTANCE OF EXPORT CREDIT INSURANCE: THE CASE OF \\ TURKEY
}

Arif DEMIRAL ${ }^{*}$

\section{Öz}

Türkiye’nin ödeme şekillerine göre ihracat verileri incelendiğinde, mal mukabili karşllı̆̆ında gerçekleştirilen ihracatın toplam ihracat gelirlerinin yarısından fazlasını oluşturduğu görülmüştür. Mal mukabili karşılığında ödeme ihracatçılar açısından rekabet avantajı sağlasa da vadeli alacakların zamanı geldiğinde tahsil edilip/edilemeyeceği belirsizdir. Alacakların zamanında tahsil edilememesi ihracatçıların likidite sıkıntısı ile karşı karşıya gelmesine yol açacak olup, ticari ve politik riskleri ortadan kaldıran ve/veya azaltan enstrümanlara ihtiyaç duyulmaktadır. Bu enstrümanların başında ülkemizde gelişmiş ülkelere kıyasla geç uygulanmaya başlanan ve özellikle kurumsal şirket yöneticilerinin son dönemlerde önem vermeye başladıkları ihracat kredi sigortası uygulamaları gelmektedir. Bu çalışmada, mal mukabili karşılı̆̆ı başka bir ifadeyle açık hesap şeklinde gerçekleştirilen ihracatın ne tür risklere maruz kaldığı, ihracatçlların bu türden riskleri nasıl asgari düzeye indirebilecekleri ve ihracat kredi sigortası uygulamalarının ihracatın gelişimine katkılarının açılanması amaçlanmıştır. Bu kapsamda Türk Eximbank’ın ihracatçılar açısından önemine değinilmiştir.

Anahtar Kelimeler: İhracat Kredi Sigortaları, Mal Mukabili Ödeme, Ticari ve Politik Riskler

Jel Kodları: F19, G22, G 23

\section{Abstract}

According to export data of Turkey in terms of payment types the portion of cash against goods is more than half of the total export. Although cash against goods provides competitive advantage in terms of exporters, whether forward looking receivables are collected or not in maturity date is uncertain. When receivables are not collected on time exports faces liquidity constraint and the instruments are required to abolish commercial and political risks and/or decrease. At the beginning of these instruments are export credit insurance implementations that are enforced late in our country compare with developed countries and attached importance by especially corporate company managers in recent times. In this study, what kind of cash against goods in other word open account type of export is exposed to, how exporters can reduce such risks to minimum level and the

* Dr., Türk Eximbank, ardemiral@gmail.com 
contributions of export credit insurance implementations to export development are aimed to be explained. In this context, in terms of exporters the importance of Türk Eximbank was mentioned.

Keywords: Export Credit Insurance, Cash Against Goods, Commercial and Political Risks

Jel Codes: F19, G22, G 23

\section{Giriş}

Bazı ülkelerde dış ticaret sigortası olarak da bilinen ihracat kredisi sigortası, uluslararası ticaretin yaygın bir uygulaması olup,19. yüzyılın ortalarında Avrupa'da ortaya çıkmıştır (Qu, 2015, s.41) Uluslararası ticaretin gelişimi bir taraftan ekonomik büyümeyi hızlandırırken, diğer taraftan şirketlerin karşılaştığı riskleri de artırmaktadır. İhracat kredisi sigortası bu riskleri asgari seviyeye indirmek için önemli bir finansal enstrümandır. İhracat kredi sigortasının temel amacı, uluslararası ticareti kolaylaştırmak, ihracatçıların uzun vadeli temerrüt, iflas veya iflas gibi ticari risklerden ve uluslararası ticaret kısıtlaması gibi politik risklerden korunmasına yardımcı olmaktır. 2016 yılı itibarıyla, ihracat kredisi sigortası tarafından desteklenen uluslararası ticaretin ölçeği 90 bin şirket için 2.8 trilyon USD’ye ulaşmıştır (Yanjing and Haiyan, 2018, 3).

Sigortacılık sektörünün bir dalı olan ihracat kredi sigortası, diğer bir deyişle alacak sigortası, taraflar arasında yapılan poliçe / sözleşme hükümleri gereği belli bir prim karşılığında, vadeli mal satışı yapan sigortalıyı mal bedelini tahsil edememesine yol açan çeşitli ticari ve politik risklere karşı güvence altına alan ve aynı zamanda bu alacakların teminat olarak kabul edilmesiyle finansman yaratma imkânı sunan bir sigorta türüdür (Stephens, 1999, 79).

İhracat kredi sigortası, ihracatçının mevcut pazar payını genişletmeyi, riskli pazarlara güvenilir bir şekilde girmeyi, vadeli satışlardan kaynaklanan riskleri azaltmayı, uluslararası rekabeti geliştirmeyi amaç edinen finansal bir enstrümandır. İhracat kredi sigortası, ihracatçının pazar payını artırması ve alacağın takip ve tahsilatını kolaylaştırması gibi özellikleri nedeniyle ihracatçı şirketlere önemli avantajlar sunmaktadır (Olhan, 2009, 30-31)

İthalat işlemlerinde mal ve hizmet alımları genellikle vadeli yapılmaktadır. Alacağın vadesi geldiği zaman ithalatçıların yükümlülüklerini yerine getirmemeleri halinde ihracatçıların sıkıntı yaşaması muhtemeldir. Alacağını tahsil edemeyen ihracatçılar da tedarikçilerine ödeme yapamayacaktır. Bu durum silsile etkisi yaratarak ticari hayatı olumsuz etkileyecektir.

İhracat kredi sigortası kapsamına ticari ve politik riskler girmektedir. Ticari risk, mal veya hizmeti satın alan ithalatçının mal bedelini ödeyememe durumunda ortaya çıkmaktadır. Politik risk, satıcıya gönderilecek olan mal bedeli olan dövizlerin alıcının ülkesindeki yetkililer tarafından gönderilmesinin kısıtlanması, savaş hali ve ithalat lisansının iptali gibi alıcının ülkesinde ortaya çıkan riskler ile ilişkilidir (Grath, 2008, 110).

Dünya üzerindeki uygulamaların birçoğunda ihracat kredi sigortası kapsamında ticari risklerden doğan zararların \% 75-90’ının, politik risklerden doğan zararların ise \% 85-95'inin karşılandığ 
görülmektedir. Politik risklerde belirsizliklerin daha çok olması sebebiyle karşılanma oranı da daha yüksektir. Sigortalı ile ihracat kredi sigortası işini yapan kuruluş arasında yapılacak anlaşma çerçevesinde risk paylaşımı farklı şekilde düzenlenebilir.

$\mathrm{Bu}$ sistemde gerçekleştirilen sevkiyatların tamamı garanti altına alınmamakta, \% 5-25 gibi bir oran her zaman için ihracatçının riski olarak kalmaktadır. Bu şekilde ihracatçının alıcılarını iyi seçmesi ve ödenmeyen alacaklarını yakından takip etmesi yükümlülüğünü getirmektedir. Böylece şirket sahiplerinin basiretli tacir gibi hareket etmesi sağlanmaya çalışılmaktadır (Fitzgerald, 1996, 64) İhracat kredi sigortası, ihracat yapan şirketlerin bilinçli hareket etmesine katkıda bulunmakta ve aynı zamanda diş ticaretin şeffaflaşmasına yardımcı olmaktadır (Bozkurt, 1988, 4).

İhracat kredi sigortası programlarının ihracatçı şirketlere çok sayıda fayda sağladığı bilinen bir gerçektir. Bu bağlamda ihracat kredi sigortasına sahip şirketler için sözleşme veya poliçede belirtilen oranda ticari alacakların tahsil edilememe riski ortadan kalkmaktadır. Risk, alacak sigortası yapan kuruluşa devredilmektedir. İhracatçılar, sigorta yapan kuruluşun alıcı hakkında yaptıkları detaylı araştırmalar sayesinde müşterilerinin son durumuna ilişkin bilgi sahibi olurlar. Finansal olarak güçlü ve zayıf olan alıcıların tespit edilmesine imkân sağlanır.

Ticari alacakların sigorta ettirilmesiyle alacak kalitesini artıran ihracatçıların bankalarda kredibilitesi artmakta ve böylece ihracatçllar bankalar ile daha esnek teminat koşullarıyla çalışma imkânını elde edebilmektedir. İhracat kredi sigortasından yararlanan şirketlerin dış pazarlarda rekabet şansı artmaktadır. İhracatçıların ilk kez satış yapmayı planladıkları riskli bölgelerde (kuzey afrika v.b.) faaliyet gösteren alıcılarına sigorta şirketleri tarafından limit tahsis edilmesi halinde ihracatçların ciro gelişimi ve kârlllığı pozitif etkilenecektir. Şöyle ki; ihracat kredi sigortası olmadan riskli ülkelere ve bölgelere satış yapmak istemeyen ihracatçılar, riski sigorta kuruluşuna devredeceği için ihracatı rahatlıkla gerçekleştirecektir. Bunun yanı sıra sigorta poliçesi kapsamında alıcılara tahsis edilen limitler teminat gösterilmek suretiyle iskonto edilerek finansman sağlanabilmektedir (Bozer, 1981, 22-23).

$\mathrm{Bu}$ çalışma ile son dönemlerde adına sıkça duymaya başladığımız ihracat kredi sigortası programlarının ihracatın gelişimine olan katkıları ve ihracatın artırılmasına önemli düzeyde destek sağlayan başta Türk Eximbank olmak üzere diğer sigorta şirketlerinin faaliyetlerine ve ihracatçılara olan desteklerine ilişkin bilgilere yer verilmeye çalışılmıştır. İhracat kredi sigortasının işleyişi ayrıntılı şekilde açıklanmıştır. Türkiye'de ihracatın ve ihracat kredi sigortası programları ile sigortalanan sevkiyatların arasındaki gelişim incelenerek ihracat kredi sigortası programlarının gerekliliği ve önemi üzerinde durulmuştur. Bu program, Türkiyede her ne kadar geç uygulanmaya başlansa da sigortalanan sevkiyat tutarlarından da anlaşılacağı üzere hızlı bir gelişim performansı sergilediği ve potansiyelinin yüksek olduğu görülmüştür.

Günümüzde gelişmiş ülkelerde etkin bir şekilde uygulanmakta olan ihracat kredi sigortasının Türkiye açısından mevcut görünümü ve ihracata olan etkilerinin incelenmesinin literatüre katkı sağlayacağı düşünülmüştür. Aynı zamanda şirketlerin faaliyetlerini sorunsuzca sürdürebilmeleri için mal mukabili karşıllğ̆ında gerçekleştirilen satışların ne türlü risklere maruz kaldığ korunma yöntemlerinden bahsedilmiştir. 


\section{I. İhracat Kredi Sigortasının Dünya'daki ve Türkiye'deki Tarihsel Gelişimi}

İhracat kredi sigortasını ilk uygulayan şirket İngiltere'de "British Commercial Insurance Company" unvanı ile kurulmuştur (Dowding, 2000, 7). İhracat kredi sigortasının ilk olarak 18. yüzyılın sonlarına doğru ortaya çıktığı düşünülmektedir. 1776 yılında Prusya’lı Profesör Wurms, yetkililere tüccarların risklerini en aza indirmek amacıyla denizcilik risklerini kapsayacak önerilerde bulunmuştur. 1839'da İtalyan yazar "Bonajuto Paris Sanguinetti”, iflasların neden olduğu zararları kapsayan makalesini yayınlamış ve makalenin içeriği incelendiğinde adı geçen yazar kredi sigortasının kurucusu olarak kabul edilmiştir.

1849 yilında "Banque Mallet Frères et Cie", ticari alacak riskini kapsayan uygulamayı ilk yapan Fransız bankası olmuştur. Daha sonra hızlı bir şekilde yaygınlaşarak Paris’te faaliyet gösteren farklı dört banka da ticari alacak riskini üstlenmişlerdir. Bu bankalar, başlangıçta önemli düzeyde başarı yakaladıktan sonra ileriki dönemlerde yaşanan olumsuz gelişmeleri takiben faaliyetlerini durdurmak zorunda kalmışlardır. Bu duruma bankacılık ve sigortacılık dalları arasındaki katı ayrımlar ve zamanla sigortalanan alıcılardan kaynaklanan vadesi geçmiş alacaklara bağlı oluşan ciddi tutarlı zararlar neden olmuştur (ICISA, 7-8). 1850'li yıllarda Almanya, Fransa, İngiltere ve Belçika'da ihracat kredi sigortası yapan şirketler kurulmuştur. İngiltere'de "The Solvency Mutual Guarantee Company", "The Commercial Debt Insurance Company" unvanlarına sahip şirketler faaliyet göstermeye başlamıştır (Claude, 1973, 44). Modern kredi sigorta sisteminin ilk oluşumu ise 1871 yılında kurulan "Ocean Accident \& Quarantee Corporation Ltd." unvanına sahip şirket ile başlamıştır. Hali hazırda faaliyetlerine devam eden şirket, geçmişte hem İngiltere'de hem de Amerika'da operasyonlarını sürdürmüştür (Pamukçu, 2002, 90).

Ülkeler arasında ortaya çıkan kısıtlamalar ve gerilimler sonrası politik riskler de teminat altına alınmış, böylece hem ticari hem de politik riskleri kapsayan ihracat kredi sigortası uygulamaya geçirilmiştir. İsviçre'de 1881 yılında sadece ticari riskler teminat altına alınırken; 1934 yllında politik riskler de sigorta edilmeye başlanmıştır (Acınan, 1997, 23). İhracat kredi sigortası uygulamaları ile birçok ülkede faaliyet gösteren gerek kamu gerekse özel alıcıların bilgileri ortak havuzda toplanmaya başlamıştır. İhracat kredi sigortası işini yapan özel ve kamu kuruluşları söz konusu havuzdan yararlanarak hem alıcıları hakkında daha detaylı bilgi sahibi olmakta hem de birbirleriyle işbirliği yapmaktadır. Ülkeler aralarındaki işbirliğini artırmak için "The International Credit Insurance Association” adı altında birlik kurmuştur (Shenkman, 1935, 141).

İhracat kredi sigortasına ihracatçıları desteklemek amacıyla ülkemizde ilk uygulamaya 1989 yılında Türk Eximbank tarafından başlanmıştır. Türk Eximbank, dünyada alacak sigortası işiyle uğraşan benzer kuruluşlarla bilgi paylaşımı yapan uluslararası kuruluş Berne Union’a 1991 yılında gözlemci üye, 1994 yllında ise tam üye olmuştur. Bern Union, ihracat kredi süreleri konusunda anlaşmayı sağlamak, ihracatın artırılmasını desteklemek amacıyla 1934 yılında bir grup ülkenin bir araya gelerek oluşturduğu birliktir (Seyidoğlu, 364).

Türk Eximbank’’n faaliyete başladığı yllarda özel sigorta şirketleri ihracat kredi sigortası işlemi yapma yetkisine sahip değildi. 2000'li ylllardan sonra özel sigorta şirketlerine Hazine Müsteşarlğ̆ı tarafından verilen lisansa sahip olmak şartı ile ihracat kredi sigortası poliçesi düzenlemesi yetkisi verilmiştir. 
İlk olarak, 2005 yılında Garanti Sigorta A.Ş., Anadolu Anonim Türk Sigorta Şirketi, Emek Sigorta A.Ş., Güneş Sigorta A.Ş., Koç Allianz Sigorta A.Ş., Toprak Sigorta A.Ş. ve Yapı Kredi Sigorta A.Ş.ye ihracat kredi sigortası branşı için yetki verilmiştir.

\section{2. İhracat Kredi Sigortasının İşleyişi}

İhracat kredi sigortası kapsamında poliçeyi tanzim eden sigortacı, alacaklarını sigorta ettiren şirket sigortalı, limit tahsis edilen şirketler ise alıcı olarak adlandırılmaktadır. İhracat kredi sigortasından faydalanmak isteyen şirketlerin ilk olarak ihracat kredi sigortası işiyle iştigal eden kuruluşlara başvurarak poliçe imzalamaları gerekmektedir.

Sigortalı, poliçe tanzimi sonrası vadeli mal satışı yaptığı alıcılarının ticaret unvanlarını, vergi numaralarını, adreslerini, ticaret sicil numaralarını, kaç gün vadeli satış yaptığını, hangi ülkeye satış gerçekleştirileceğini, bir yıl içerisinde ne kadar mal sevkiyatı yapacağını, ödeme şekli ve teminat koşullarına ilişkin bilgilerin yer aldığı başvuru formunu sigorta şirketine bildirir.

Sigorta şirketi de kendisine bildirilen formda yer alan bilgiler doğrultusunda sigortalının alıcıları hakkında analiz yapabilmek için bilgi toplamaya başlar. Alıcılara ilişkin elde edilen bilgilere istinaden underwriterlar (limit tahsis yetkilileri) tarafından sigortalının alıcılarına limit tahsisi gerçekleştirilir.

Genellikle, limit tahsis sürecinde sigortalının alıcılarının hepsi adına tek tek çalışma yapılır. Ancak; bazı sigorta şirketleri, belirli tutarların altında limit talep edilen alıcılara ilişkin çalışma yapmamaktadır. Söz konusu çalışma yapılmayan alıcılara ilişkin ödenecek toplam tazminat tutarı ve toplam alıcı sayısı gibi kriterler önceden belirlenerek otomatik limit tahsis edilmiş gibi değerlendirilmektedir. Bu yöntem, sigortalıya hızlı cevap vermek, operasyonel iş yükümlülüklerini azaltmak nedeniyle tercih edilmektedir.

Değerlendirme aşamasında limit tahsis edilmeyen alıcılar ile karşılaşılabilir. Moraliter olumsuzluk olması (karşılıksız çek, protestolu senet, icra ve haciz kayıtları v.b.), özkaynakların yetersiz olması, şirketin fesholması, şirketin faaliyetlerini durdurması, şirketin iflas etmesi, şirketin konkordato sürecine girmesi, alıcı hakkında detaylı bilgi sağlanamaması v.b. haller limit tahsis edilmeme sebeplerinden bazılarıdır.

Sigorta şirketi, alıcıya neden limit tahsis edilmediğine ilişkin bilgiyi sigortalı ile paylaşır. Sigortalının alıcısına limit tahsis edilmese de sigortalıya alıcısı hakkında verilen önemli bilgiler sayesinde sigortalının ileride karşılaşması muhtemel risklerden (alacağın vadesinde tahsil edilememe riski) korunmasına yardımcı olunur. İhracat kredi sigortası programında, limit tahsis sürecinin daha iyi anlaşılabilmesi için bunu bir örnek ile açıklamaya çalışalım.

\section{I. Limit Tahsis Süreci}

Underwriter, alıcılara tahsis edilecek limit için sigortalı ve alıcı arasındaki yıllık satış hacmini ve çalışma vadesini dikkate alarak değerlendirme yapar (Jus, 2013, 124). 


\section{Örnek:}

Alıcıya tahsis edilecek limit belirlenirken ilk olarak alıcıya bir yıl içerisinde tahmini olarak ne kadar satış yapılacağı ve bu satışların vadesinin ne olacağı bilgisine ihtiyaç duyulmaktadır. Sigortalı, alıcısına 2 ay vadeli yıllık 6.000.000 USD satış gerçekleştiriyorsa; bir yıl içinde satış vadesi 6 kez devredeceği için 1.000.000 USD limit, sigortalının 6.000.000 USD iş hacmi yapmasına imkân tanıyacaktır. Aynı örnek için; çalışma vadesinin 4 ay olması halinde ( 3 kez devir) limit ihtiyacı aşağıda görüleceği gibi 2.000.000 USD olacaktır.

Yillık Tahmini Ciro: 6.000.000 USD Yillık Tahmini Ciro: 6.000.000 USD

Kredi Dönemi (Vade): 2 Ay Kredi Dönemi (Vade): 4 Ay

Kredi Limiti: 1.000.000 USD Kredi Limiti: 2.000.000 USD

Burada, yıl içerisinde gerçekleştirilen satışların dengeli dağıldığı ve yüksek tutarlı tek bir satışın olmadığı varsayımı dikkate alınarak limit ihtiyacı belirlenmiştir.

\section{2. İhracat Kredi Sigortası Programlarında Prim Hesaplama Yöntemleri}

İhracat kredi sigortası ile iştigal eden kuruluşlar üstlendikleri risklerin karşıllı̆̆ında prim geliri elde etmektedir. Bazı sigorta şirketleri ciro bazlı; bazıları ise sevkiyat bazlı prim sistemini kullanmaktadır. Ciro bazlı sistemde tahmini ciro beklentisinin belli bir yüzdesi karşılığında alacaklara prim işletilirken; sevkiyat bazlı sistemde her fatura bazında ayrı ayrı prim hesaplanmaktadır.

Ciro bazlı sistemde prim hesaplamasının nasıl yapıldığını bir örnek ile açıllamaya çalışalım.

Örnek: XYZ, 1990 yllından beri tekstil sektöründe faaliyet gösteren 100'den fazla ülkeye ihracat gerçekleştiren bir şirkettir. İhracat yaptığı ülkeler arasında AB ülkeleri, ABD ve Güney Amerika ülkelerinin yanı sıra yüksek riskli kabul edilen Afrika ülkeleri de yer almaktadır. XYZ şirketi 6 aya kadar vadeli sevkiyatlarını (mal mukabili, vesaik mukabili) sigorta ettirmek için ihracat kredi sigortası şirketi ile poliçe imzalamıştır.

XYZ şirketinin alacak sigortasına iliş̧in bilgileri aşağıda yer almaktadır.

Tahmini Ciro Beklentisi: 100.000.000 USD

Sigorta Prim Oranı: 0,003

Prim Bedeli: 100.000 .000 USD ${ }^{*} 0,003=300.000$ USD

\section{Kapsam Oranı (Ticari ve Politik Risk): \% 90}

Sigortalı, 300.000 USD prim ödeyerek vadeli alacaklarını olası ticari ve politik risklerden hedge edebilecektir. Burada XYZ şirketinin alıcılarına ilişkin yapılan ön çalışmada prim oranı 0,003 olarak belirlenmiştir. Prim oranlarının belirlenmesinde alıcıların finansal kapasitesi, alıcıların faaliyet gösterdiği 
ülkeler, satış vadesi, ödeme şekli, alıcıların özel veya kamu şirketi olması, sigortalının finansal durumu ve geçmiş dönem performansı v.b. kriterler dikkate alınarak hesaplama yapılmaktadır.

Örnek üzerinden devam edecek olursak, XYZ şirketinin Almanya'da faaliyet gösteren ve ihracat kredi sigortası kurumu tarafından 1.000.000 USD limit tahsis edilen alıcısının, borcunu ödeyemediğini ve iflas ettiğini varsayalım. İhracat kredi sigortası şirketi, XYZ şirketinin müşterisine tahsis ettiği limitin \% 90’ını; başka bir deyişle 1.000.000 USD * 0,90 = 900.000 USD tazminat ödemekle yükümlü olacaktır.

\section{Toplam Ödenen Prim: 300.000 USD}

\section{Tazminat Tutarı: 900.000 USD}

Bu örnekten anlaşılacağı üzere, 300.000 USD prim ödeyen ve karşılığında 900.000 USD tazminat bedelini tahsil eden XYZ şirketinin ihracat kredi sigortası işleminden kârı 600.000 USD olacaktır. Burada borçlarını ödeyemeyen tek bir şirketten bahsedilmiştir. Borçlarını ödeyemeyen alıcı sayısı birden fazla olabileceği gibi, alıcıların tamamı da yükümlülüklerini zamanında yerine getirebilir.

Sigorta şirketleri, genellikle ticari alacağın \% 90’ına kadarını tazmin etmekle yükümlüdür. Ticari alacak riskinin \% 10’luk kısmı ise sigortalı üzerinde kalmaktadır. Bu paylaşım oranları taraflar arasında yapılan anlaşmaya bağlı olarak yeniden düzenlenebilir. Burada anlatılması gereken diğer önemli nokta ise sigorta şirketlerinin de üstlendiği riskleri reasüre ederek (reinsurance) risk paylaşımına gitmeleridir. Sigorta şirketleri, reasürans şirketleri ile hem riski hem de prim gelirlerini aralarındaki anlaşmaya bağlı olarak paylaşmaktadır. Sigorta ve reasürans şirketleri arasında risk paylaşımının eşit (\% 50 - \% 50) olduğunu varsayalım. Böyle bir durumda yukarıdaki örnekte ödenen tazminat tutarının \% 50'si olan 450.000 USD reasürans şirketi tarafından karşılanacaktır. Aynı şekilde toplam prim gelirinin \% 50’si olan 150.000 USD prim geliri de sigorta şirketi tarafından reasürans şirketine aktarılacaktır.

\section{Türkiye'de İhracat Kredi Sigortası Sektörü ve Performansı}

Tarihsel gelişim içerisinde, ihracat kredi sigortası kuruluşları; özel sermayeli kuruluşlar ve kamu sermayeli resmi destekli ihracat kuruluşları olmak üzere ikiye ayrılmaktadır. Türkiye’de kamu sermayeli Türk Eximbank dışında ihracat kredi sigortası hizmeti sunan özel ve yabancı sermayeli üç büyük sigorta şirketi faaliyet göstermektedir. Bunlar Euler Hermes, Coface ve Atradius sigorta şirketleridir. Bu bölümde sigorta şirketlerinin ülkemizdeki faaliyetlerine, Türkiye ihracatına olan desteklerine değinilmiştir. Bunun yanı sıra Türkiye ihracatının yıllar itibariyle gelişimi, ihracatın ödeme şekillerine göre dağılımı ve Türkiye ihracatının Türk Eximbank tarafından sigortalanan kısmı dikkate alınarak değerlendirmeler yapılmıştır.

\section{Türk Eximbank}

İhracat kredi sigortasına ihracatçıları desteklemek amacıyla ülkemizde ilk uygulamaya 1989 y1lında Türk Eximbank tarafından başlanmıştır. Türk Eximbank, ihracatın artırılması, ihraç edilen 
ürünlerin çeşitlendirilmesi ve ihracatçı şirketlerin rakipleriyle rekabet edecek düzeye gelmesi için ihracatçılara, ihracata yönelik mal üreten imalatçılara ve yurt dışında faaliyet gösteren müteahhitlere kısa, orta ve uzun vadeli nakdi kredi desteği sağlamaktadır.

Türk Eximbank, bunun yanı sıra ihracat yapan şirketleri sigorta ve garanti programları ile desteklemektedir. Türk Eximbank, kredi ve garanti hizmetlerini tek çatı altında sunan nadir bankalar arasındadır. Bu iki hizmetin tek bir çatı altında sunulması ihracatçlların farklı ihtiyaçlarına cevap verilmesine imkân tanımaktadır (https://www.eximbank.gov.tr/tr/hakkimizda/kurumsal/bankamiz-hakkinda).

Türk Eximbank’in 2007-2017 yıllarında ihracat kredi sigortası kapsamında sigortaladığı sevkiyat tutarlarının gösterimi Grafik 1'de sunulmuştur.

\section{Grafik I: Türk Eximbank Sigortalanan Sevkiyat Tutarı (2007-20I7)*}

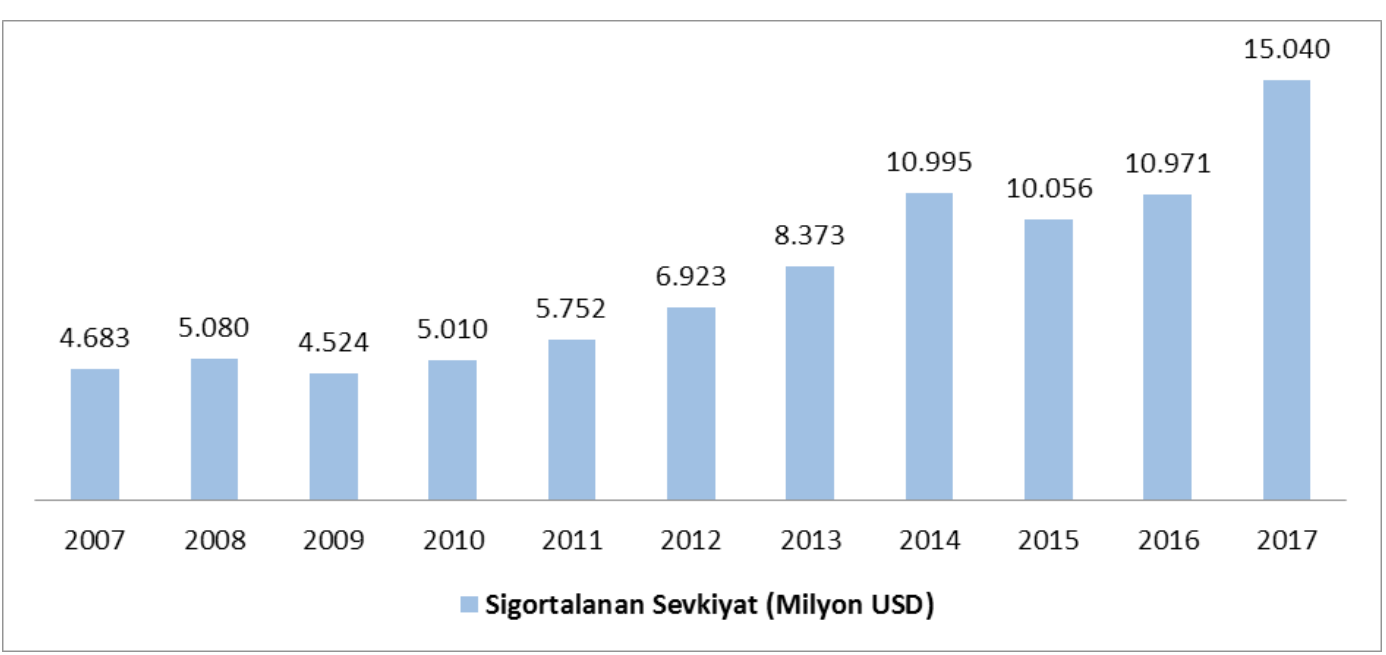

Kaynak: Türk Eximbank Faaliyet Raporları

${ }^{*}$ Sigortalanan sevkiyat tutarları kısa, orta ve uzun vadelinin toplamıdır. Ancak yukarıdaki grafikte yer alan sigortalanan sevkiyatların neredeyse tamamı kısa vadeli ihracat kredi sigortası kapsamında gerçekleştirilmiştir. Bu durumu Türkiye ihracatının kısa vadeli yapıda olması ile açıklayabiliriz.

Grafik 1 analiz edildiğinde; 2009 ve 2015 yıllarında sigortalanan sevkiyatlarda düşüşs söz konusu iken; inceleme dönemlerinde genel olarak artış eğiliminin olduğu görülmüştür. 2009 yllında küresel krize bağlı olarak Dünya ticaret hacmindeki gerileme Türkiye ihracatının da gerilemesine sebep olmuştur. 2015 yılında ise ihracatta \% 8,7 oranında daralma yaşanmıştır. İhracatın daralmasında TL'de yaşanan değer kayıpları, dünya ticaret hacmindeki gerilemeler, bazı ülkelerle yaşanan diplomatik sıkıntılar ile Suriye, Irak gibi Orta Doğu'da yer alan ülkelerde ortaya çıkan olumsuz gelişmeler etkili olmuştur. Buna bağlı olarak da 2009 ve 2015 yıllarında sigortalanan sevkiyatlarda azalma 
eğilimi ortaya çıkmıştır. 2016 yılı ile birlikte sigortalanan sevkiyatlarda tekrar artış eğilimi görülmüş olup, özellikle 2017 yılında bir önceki yıla göre sigortalanan sevkiyatlar 4 milyar USD’nin üzerinde $\% 38$ oranında artmıştır.

\section{Euler Ermes}

1893’te Amerika'da kurulan ACI, 1917'de Almanyada kurulan Hermes ve 1927'de Fransa'da kurulan SFAC şirketleri 2002 yılında bir araya gelerek Euler Hermes'i kurmuşlardır. Euler Hermes hisseleri, Paris Borsası'nda 2000 yılından beri işlem görmekte olup, Euler Hermes'in 2016 yıl sonu itibariyle hisselerinin \% 63’ü dünyanın en büyük sigorta şirketlerinden biri olan Allianz’a ait, \% 35,5’i ise borsada işlem görmektedir. Euler Hermes, 2,6 Milyar Euro'luk konsolide cirosu ve dünya çapında \% 34 'lük pazar payıyla alacak sigortası yapan en büyük şirketler arasındadır.

Euler Hermes, 2005 yllında Koç Allianz Sigorta işbirliğiyle Türkiye pazarına girmiş̦tir. 2010 yılında Hazine Müsteşarlığı’ndan lisans izni alarak Türkiye'de faaliyet göstermeye başlamıştır. Ticari ve politik risklere yönelik yurt içi ve yurt dışı alacakların sigortalanması konusunda hizmet sunmaktadır (http://www.eulerhermes.com.tr/tr/euler-hermes-turkiye/Pages/turkiyede-euler-hermes.aspx).

\section{Coface}

Coface, 1946 yılında Fransız menşeli bir şirket olarak kurulmuş olup, 1994 yllında özelleştirilmiştir. 2006 yılında Coface’ın mülkiyetinin tamamı, Fransảnın en büyük ikinci bankacılık grubu olan BPCE Grubun içinde yer alan Natixis’e devredilmiştir. 2014 yılı Temmuz ayı itibariyle ortaklık yapısı son şeklini almış olup, \%54,5'i halka, \%41,24'ü Natixis'e ve \%0,26's ise çalışanlara aittir. Coface, 1997 yılında Türkiye pazarına girmiş olup, ticari alacak sigortasının tanıtılmasında önemli rol üstlenmiştir. 1998 yılında Coface ve Garanti Sigorta A.Ş. arasında imzalanan işbirliği anlaşması kapsamında, Türkiye'de ilk yurt içi ticari alacak sigortasını hizmete sunmuştur. 2007 yılında Coface, Hazine Müsteşarlığı’ndan ticari alacak sigortası lisansını alarak, Coface Sigorta A.Ş. unvanı ile Türkiyede faaliyet gösteren yabancı, özel sermayeli ilk ticari alacak sigortası şirketini kurmuştur (http://www.coface. com.tr/coface-hakkında/coface-genel/tarıhcemız).

\section{Atradius}

Atradius, 1925 yılında şirketlerin ticari hacimlerini artırmak amacıyla Hollanda'da NCM (Nederlandsche Credietverzekering Maatschappij) unvanı ile kurulmuştur. Alman kredi sigortası grubu, Gerling-Konzern Speziale Kreditversicherung (Gerling Credit) ile Hollandalı kredi sigortası şirketi NCM’nin birleşmesi üzerine 2001'de kurulan kredi sigortası ve alacak yönetimi alanında faaliyet gösteren GERLING NCM’nin ismi Ağustos 2003'te Atradius olarak değiştirilmiştir. Dünya'da 50’den fazla ülkede faaliyet gösteren Atradius'un yıllık konsolide cirosu 1.6 Milyar Euro civarındadır. Türkiye'de 2007 yllından beri faaliyet göstermektedir (https://atradius.com.tr/article/atradius-t\%C3\%BCrkiye.html). 
Euler Hermes, Coface, Atradius ve diğer sigorta şirketlerinin 2016-2017 yılları arasında Türkiye pazarından elde ettikleri prim gelirleri ve pazar payları aşağıda yer almaktadır.

Tablo I: Kredi Sigortası Prim Gelirleri Listesi (2016-2017)*(TL)

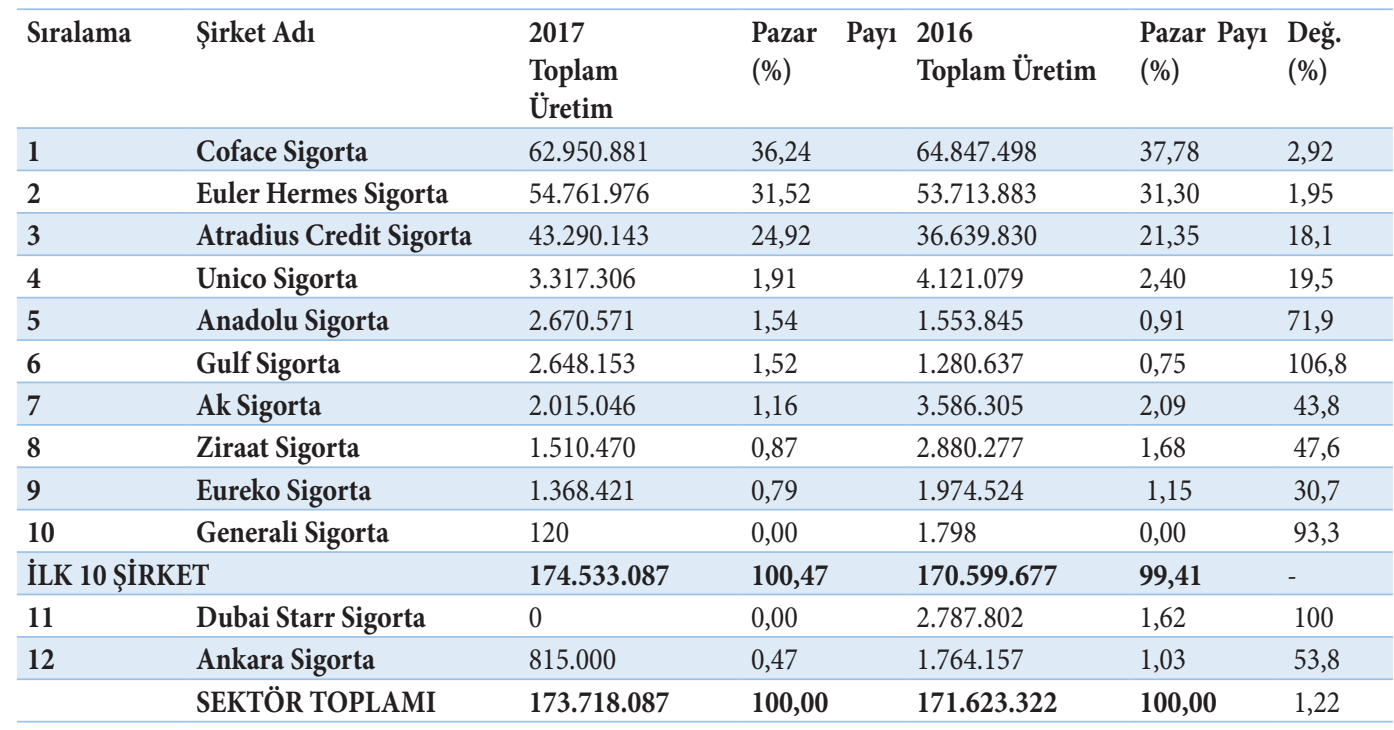

Kaynak: Türkiye Sigorta, Reasürans ve Emeklilik Şirketler Birliği

*Sigorta şirketlerinin elde ettikleri prim gelirlerinin yurt içi ve yurt dışı dağılımı bilinmemektedir.

2017 yılında kredi sigortası sektörünün ürettiği toplam prim gelirleri 171,6 milyon TL'den 173,7 milyon TL’ye yükselmiştir. Toplam prim gelirlerinin neredeyse tamamı ilk 10 özel sigorta şirketi tarafından elde edilmiştir. Üretilen prim gelirleri açısından alacak sigortası pazarının yaklaşık \% 93’lük kısmının üç büyük sigorta şirketi (Euler Hermes, Coface ve Atradius) tarafından kontrol edildiği görülmüştür. 2016 yılı itibariyle prim gelirleri açısından pazar payı en yüksek olan Coface Sigorta’nın, 2017 yılında pazar payı \% 36,24’e gerilemiştir. Her ne kadar Coface Sigorta’nın pazar payı gerilemiş olsa da en yakın rakibi olan Euler Hermes'in pazar payının kısmi artması sebebiyle birinci sıradaki yerini korumuştur.

2017 yılında pazar payını genişleten en önemli üç sigorta şirketi Atradius, Anadolu ve Gulf olmuştur. Üç büyük sigorta şirketi arasında Atradius'un hızla büyümesi dikkat çekmektedir. 2017 y1lında yüzdesel bazda en hızlı büyüyün şirket ise Gulf Sigorta'ır. 2017 yılında Coface, Unico, Ak, Ziraat, Eureko, Generali, Ankara ve Dubai Starr sigorta şirketlerinin pazar payı gerilemiştir. Dubai Starr sigorta şirketinin 2017 yılında prim geliri elde etmediği görülmüştür. Bu alacak sigortası faaliyetlerini durdurduğu anlamına gelmektedir. Yukarıdaki tablodan da anlaşılacağı gibi inceleme dönemlerinde Ankara Sigorta şirketinin prim gelirinin aksine prim zararına katlandığı gözlenmiştir.

Türkiye ihracatının önemli kısmı mal mukabili satışlardan oluştuğundan bu satışların ne kadarlık kısmının ticari ve politik risklerden korunduğu önem arz etmektedir. Mal mukabili karşılı̆̆ında 
yapılan satışlarda Türk Eximbank’’n teminatına giren kısmı incelenerek riske maruz kısım hakkında değerlendirme yapılmaya çalışılmıştır.

Grafik 2'de 2007-2017 yılları arasındaki toplam ihracat, bu ihracat içerisindeki mal mukabili satışlar ve Türk Eximbank tarafından sigortalanan sevkiyatlara yer verilmiştir.

Grafik 2:Toplam İhracat, Mal Mukabili İhracat ve Eximbank Sigortalanan Sevkiyat Tutarı Gelişimi (2007-2017)*

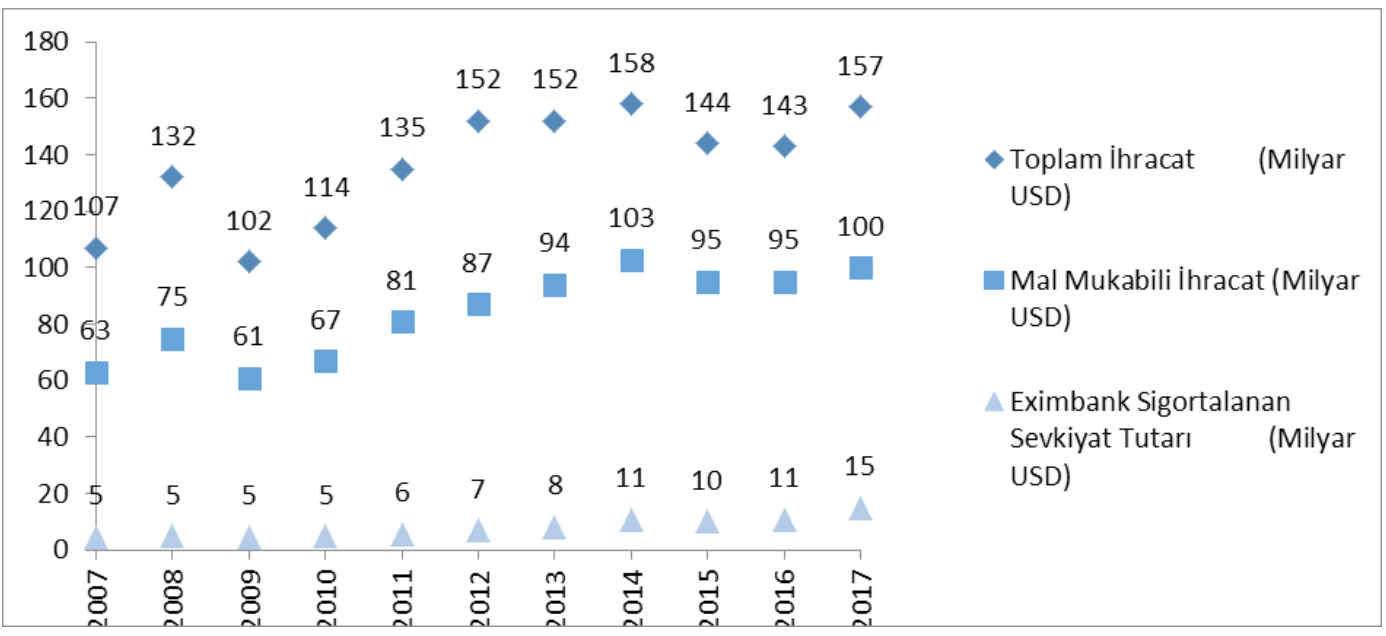

Kaynak: TÜİK, Türk Eximbank Faaliyet Raporları,

*Türk Eximbank tarafından sigortalanan sevkiyat tutarı, ihracatçı şirketlerin hem yurt dışı hem de yurt içi sigortalattığı alacaklarının toplamını ifade etmektedir.

Grafiğe göre; Türkiye ihracatının 2009 yılına kadar artış gösterdiği görülmektedir. 2008 yılında ortaya çıkan ve piyasalarda etkisini ağırlıkla 2009 yılında hissettiren küresel kriz sonrası ihracat hacminde ciddi daralma yaşanmıştır. Bu bağlamda 2008 yılında 132 milyar USD olan ihracat tutarı, bir sonraki yıl takribi 30 milyar USD gerileyerek 102 milyar USD olmuştur.

2010-2012 yılları arasında ise ihracat tekrar artış eğilimine girmiştir. 2013 yılında bir önceki yıla göre kısmi gerileme yaşansa da, 2014 yılında ihracat tekrar artış göstererek 158 milyar USD’ye ulaşmıştır. 2015 ve 2016 yıllarında ihracat gerilerken; 2017 yılında tekrar artış eğilimi görülmüştür.

İnceleme dönemlerinde, mal mukabili ihracat ve toplam ihracatın gelişimi paralellik arz etmiştir. Mal mukabili ihracat toplam ihracat azaldığında azalış; arttığında ise artış eğilimine sahip olmuştur. Türkiye’nin toplam ihracatının ağırlıklı kısmının mal mukabili karşılığında gerçekleştirmesi nedeniyle ticari ve politik risklere maruz kalınmaktadır. Bu risklerin ne ölçüde hedge edilebildiği önem arz etmektedir. Türk Eximbank 2017 yılında mal mukabili ihracatın takribi \%15'ini garanti altına aldığı görülmektedir. 2017 yılında bir önceki yıla göre ihracat kredi sigortası desteği \%38 oranında artırılmıştır. 
2014 yılında gerçekleştirilen bir çalışmada Eke, 2002-2012 yılları arasında mal mukabili karşılığında gerçekleştirilen ihracatın ihracat kredi sigortaları ve ihracat faktoring işlemleri ile takribi \%20'lik kısmının teminat altına alınabildiğini hesaplamıştır (Eke, 2014, s.71). Söz konusu orandan da anlaşılacağı üzere teminat altına alınmayan alacakların nedenleri araştırılmalı, şirketlerin kurumsal risk bakış açılarının geliştirilmesi ve ihracat kredi sigortası programlarından faydalanan şirket sayısının artırılması önem arz etmektedir.

Türkiye ihracatını mal mukabili, vesaik mukabili, peşin, akreditif ve diğer ödeme şekilleriyle gerçekleştirmektedir. Türkiye’nin 2007-2017 yılları arasında ödeme şekillerine göre ihracatı Grafik 2'de sunulmuştur.

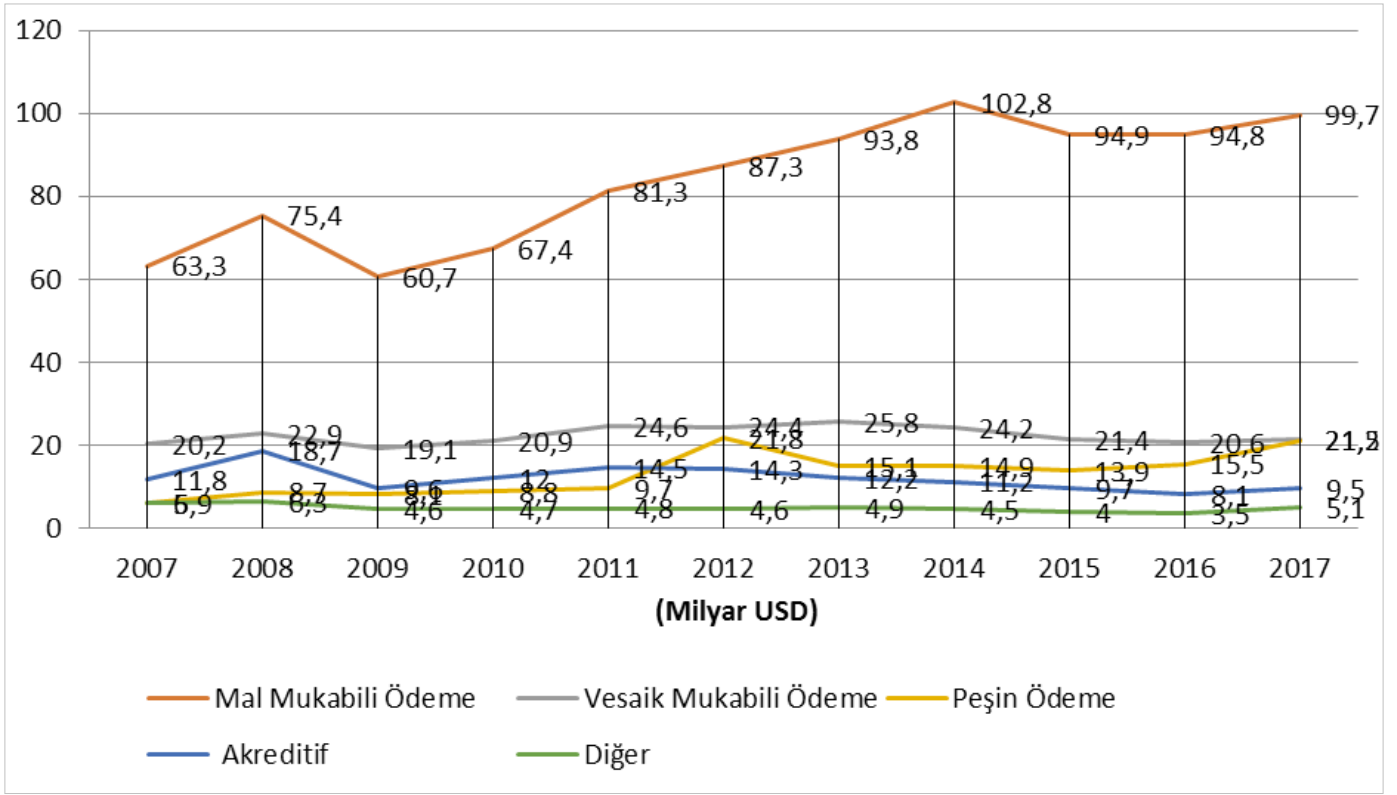

Kaynak: Türkiye İhracatçllar Meclisi

İnceleme dönemlerinde ihracatta en çok tercih edilen ödeme şekilleri sırasılyla mal mukabili, vesaik mukabili, peşin ve akreditif olmuştur. 2007-2017 yılları arasında mal mukabili karşıllı̆̆ satışlar (\%57-66) ihracatta en çok tercih edilen ödeme şekli olmuştur. Ticari alacakların tahsil kabiliyeti açısından en riskli satış yöntemi mal mukabilidir. Ticari alacağın vadesi geldiği zaman tahsilatın yapılıp yapılamayacağı belirsizdir. Çünkü alacak herhangi bir garantiye bağlanmamıştır. Alıcı ve satıc1nın karşılıklı güven ilişkisine dayalı ileri vadeli ticaret söz konusudur.

En çok kullanılan ödeme şekillerinden ikincisi ise vesaik mukabili ödeme şekli olup, 2017 yllında toplam ihracat içindeki payı \% 13,7 olmuştur. Vesaik mukabili ödeme şeklinin payı yıllar itibariyle azalan seyir izlemiştir. Üçüncü en çok tercih edilen ödeme şekli ise peşin ödeme olmuştur. Peşin ihracatın payı son dönemlerde artan seyir izlemiştir. 2017 yılında toplam ihracatın \% 13,5'i peşin bedelle gerçekleştirilmiştir. 
Bu ilk 3 ödeme şeklinin dışında en fazla payı akreditifli satışlar oluşturmuştur. Peşin ve akreditifli satışlar tüm dünya ülkelerindeki ihracatçıların en çok tercih etmek isteyeceği ödeme şekilleridir. 2017 yılında her iki ödeme şeklinin de artması (özellikle peşin satışlar), Türk ihracatçların daha garantili satış yapmak istediklerini göstergesi olarak karşımıza çıkmaktadır. Türkiye’deki şirketlerin ihracattan doğan alacaklarını zamanında ve sorunsuzca tahsil edebilmesi için garantili satış yöntemlerini daha fazla tercih etmeleri ve ihracat kredi sigortası programlarından, ihracat faktoringinden daha fazla faydalanmaları gerektiği düşünülmektedir.

\section{Sonuç}

İhracat kredi sigortası programı gelişmiş ülkelerde 18. yüzyılın sonlarına doğru uygulanmaya başlanırken, ülkemizde ilk uygulamaya 1989 yılında Türk Eximbank tarafından başlanmıştır. Ülke ekonomisi ve ihracatçılar açısından önemi yüksek düzeyde olan ihracat kredi sigortası enstrümanının kullanımına gelişmiş ülkelere kıyasla geç başlandığı görülmüştür. Bu bağlamda Türkiye'de alacak sigortası kullanım yaygınlığı Avrupa ülkelerine göre hala düşük düzeylerde olduğu söylenebilir.

Bu çalışmada, ihracatçların maruz kalabileceği ticari ve politik risklerin değerlendirilmesi amacıyla ihracatın ödeme şekilleri itibarıyla dağılımı ve Türk Eximbank’ın ihracat kredi sigortası kapsamında sigortaladığı sevkiyatlar incelenmiştir. 2017 yılında 15,04 milyar USD’lik ihracat Türk Eximbank tarafından sigorta kapsamına alınmıştır. Türk Eximbank’ın 2017 yılında bir önceki yıla göre ihracat kredi sigortası desteği \%38 oranında artııştır. Türkiye ihracatının söz konusu yılda 99,7 milyar USD’lik kısmının mal mukabili karşılığında gerçekleştirildiği dikkate alınacak olunursa; Türk Eximbank tek başına açık hesaplı alacakların yaklaşık \% 15'ini teminat altına almıştır.

İhracatı teşvik etmek ve desteklemek amacıyla faaliyetlerini sürdüren Türk Eximbank, ihracatçlar için önemli bir kuruluştur. Türk Eximbank’n tek başına sağladığı destek önemli olmakla birlikte; diğer finansal kuruluşlarında desteği alacakların sorunsuzca tahsil edilebilmesi açısından büyük önem arz etmektedir. İnceleme dönemleri itibariyle diğer ihracat kredi sigortası şirketlerinin de elde ettikleri prim gelirlerindeki artışlardan anlaşılacağı üzere alacak sigortası pazarının piyasada önemi giderek artmaktadır.

2017 yılında mal mukabili karşılığı ödemenin ihracattaki ödeme şekilleri içindeki payı $\% 63,5$ olarak gerçekleşmiş olup, en çok tercih edilen ödeme şekli olmuştur. Ticari alacakların tahsil kabiliyeti açısından en riskli satış yöntemi mal mukabilidir. Ticari alacağın vadesi geldiği zaman tahsilatın yapılıp yapılamayacağı belirsizdir. Çünkü alacak herhangi bir garantiye bağlanmamıştır. Alıcı ve satıcının karşılıklı güven ilişkisine dayalı ileri vadeli ticaret söz konusudur. Bu türden alacakların ihracat kredi sigortası programları ile sigorta altına alınmasıyla, ihracatçılar ticari ve politik riskleri bertaraf edecekler aynı zamanda kurumsal risk yönetimi ilkelerine uyum sağlayacaklardır.

Ticari alacakların tahsilatında yaşanan problemlerin, şirketlerin likiditesini ve kârlıllğını olumsuz etkilediği hatta bazı durumlarda şirketlerin iflasına neden olduğu bilinen gerçeklerdir. İhracatın garantili bir şekilde yapılması, ihracatın sürdürülebilirliği ve ekonomik büyümenin sağlanması açısından önemlidir. Bu nedenle Türkiyede ihracat satışlarının önemli kısmının garanti altına alınmadan 
yapıldığı için teminat altına alınmayan alacakların nedenleri araştırılmalı, şirketlerin kurumsal risk bakış açıları geliştirilmeli, küresel risklerin yüksek olduğu dönemlerde daha garantili satış yöntemleri (peşin, akreditif gibi) tercih edilmeli, ihracat kredi sigortası programları ve ihracat faktoringi işlemlerinden faydalanan şirket sayısının artırılması gerekmektedir.

\section{KAYNAKÇA}

ACINAN, Hilmi. İhracat Kredi Sigortası Ders Notları, İstanbul Üniversitesi Sosyal Bilimler Meslek Yüksek Okulu Diş Ticaret Programı, İstanbul, 1997, s. 23

BOZER, Ali. Genel Açıdan İhracat Kredi Sigortası, İhracat Kredi Sigortası Semineri, Ankara: A.İ.T.̇..A. Gazetecilik ve Halkla İlişsiler Yüksekokulu Basım Evi, 14/15 Nisan 1981, s.19.

CLAUDE, Lilly Clifford. Governmental Export Credit Insurance In The United States, The United Kingdom, Japan And The Federal Republic Of Germany, Georgia: Georgia State Of Universty School Of Business Administration, 1973. s.44.

DOWDING, Tony. Developments in Credit and Political Risk Insurance, ICIA International Credit Insurance Association Publication, 2000, s.7.

EKE, Selda. Türkiye İhracatının Ticari Riskler Açısından Değerlendirilmesi ve Açık Hesap İhracatın Teminat Altına Alınması, Finansal Araştırmalar ve Çalışmalar Dergisi, 2014, s.71.

FITZGERALD, Thomas M. JR. Protecting Against Credit And Political Risk, Source Journal of Accountancy, Vol:181, No:1, 1996, s.64.

GRATH, Anders. The Handbook of International Trade and Finance, Second Edition, London: Kogan Page, 2008, s.110.

ICISA, A Guide To Trade Credit Insurance, First Edition, London: Anthem Press, 2015, ss.7-8.

JUS, Miran. Credit Insurance, First Edition, Oxford: Academic Press, 2013, s.124.

OLHAN, Zehra. “Türkiye'de İhracatın Desteklenmesinde İhracat Kredi Sigortası ve Uygulama Çalısması”, (Yayınlanmamış Yüksek Lisans Tezi, Marmara Üniversitesi Bankacılık ve Sigortacılık Enstitüsü, 2009), ss.30-31.

PAMUKÇU, E. Baturalp. İhracat Kredi Sigortasının Türkiye Açısından Değerlendirmesi, (Yayınlanmamış Doktora Tezi, Marmara Üniversitesi Bankacılık ve Sigortacılık Enstitüsü, 2002), s.90.

QU, Nannan."Research on the Legal System of the Export Credit Insurance in China's Foreign Trade", Voice of the Publisher, 2015, s.41.

SEYİDOĞLU, Halil. Uluslararası Finans, 2. Baskı, İstanbul: Güzem Yayınları, 1994, s.364.

SHENKMAN, Elia M. Insurance Against Credit Risk In International Trade, London: Ps King \& Son Press, 1935, s.141.

STEPHENS, Malcolm. The Changing Role of Export Credit Agencies, International Monetary Fund Publications, 1999, s.79.

TÜRK EXIMBANK, Dış Ticaretin Finansmanında 10. Yıl (1987 - 1997), Ankara: Aksoy Matbacılık, 1997, s.83. YANJING, Shi \& HAIYAN, Wang. “Game Analysis of Risk Factors under Export Credit Insurance Finance,"Asia-Pacific Journal of Risk and Insurance, De Gruyter, vol. 12(2), 2018 July, s.3.

\section{Internet Kaynakları}

Türkiye İhracat Kredi Bankası A.Ş., Kurumsal, https://www.eximbank.gov.tr/tr/hakkimizda/kurumsal/bankamiz-hakkinda (26 Nisan 2018). 
Euler Hermes, Hakkımızda, http://www.eulerhermes.com.tr/tr/euler-hermes-turkiye/Pages/turkiyede-euler-hermes.aspx(01 Mayıs 2018).

Coface, Tarihçemiz, http://www.coface.com.tr/coface-hakkında/coface-genel/tarıhcemız (01 Mayıs 2018).

Atradius, https://atradius.com.tr/article/atradius-t\%C3\%BCrkiye.html(02 May1s 2018) 